\title{
The Insulin Receptor and the Molecular Mechanism of Insulin Action
}

\author{
C. Ronald Kahn and Morris F. White \\ Research Division, Joslin Diabetes Center, Department of Medicine, Brigham and Women's Hospital \\ and Harvard Medical School, Boston, Massachusetts 02215
}

In humans and most other vertebrates, the primary hormone involved in control of blood glucose is insulin. Insulin acts on cells to stimulate glucose, protein, and lipid metabolism, as well as RNA and DNA synthesis, by modifying the activity of a variety of enzymes and transport processes. The importance of understanding insulin action is not limited to simply satisfying the intellectual needs of the curious biochemist or cell biologist. Elucidating the molecular pathways of insulin action forms an important cornerstone upon which to unravel the pathogenesis of non-insulin-dependent (type II) diabetes mellitus and a major component of other insulin-resistant states including obesity, uremia, glucocorticoid, and growth hormone excess, as well as a variety of rarer genetic disorders such as leprechaunism, the type A syndrome of insulin resistance, and lipoatrophic diabetes.

The actions of insulin at the cellular level are initiated by insulin binding to its plasma membrane receptor (1-4). This receptor is present on virtually all mammalian tissues, although the concentration varies from as few as 40 receptors on circulating erythrocytes to more than 200,000 receptors on adipocytes and hepatocytes. Like the surface membrane receptors for other hormones and growth factors, the insulin receptor serves at least two functions. The first is to recognize the hormone among all other substances in the blood. This is accomplished by binding the hormone with high affinity and a high degree of specificity. The second function is to produce a transmembrane signal that alters intracellular metabolism and mediates the action of the hormone. Recognition of the insulin molecule by its receptor is a complex molecular event and is closely linked to signal transmission. The binding domain of the insulin molecule is composed of distant portions of the $\mathrm{A}$ and B chains, which come together on one surface as a result of three-dimensional folding to form the receptor binding region (5). Among over 200 analogues of insulin studied, there is an almost perfect correlation between receptor-binding affinity and biological effect $(1,5,6)$. No competitive antagonists of insulin action at the receptor level have, as of yet, been uncovered, suggesting that the structural requirements for binding include all the features necessary for biological action. Interestingly, the binding properties of the insulin receptor are better conserved in evolution than are the properties of the insulin molecule itself (7).

Address reprint requests to Dr. C. Ronald Kahn, Joslin Diabetes Center, One Joslin Place, Boston, MA 02215.

Received for publication 29 June 1988.

J. Clin. Invest.

(c) The American Society for Clinical Investigation, Inc. 0021-9738/88/10/1151/06 \$2.00

Volume 82, October 1988, 1151-1156
The insulin receptor is a heterotetrameric glycoprotein consisting of two $\alpha$-subunits of $M_{\mathrm{r}}=135,000$ and two $\beta$-subunits of $M_{\mathrm{r}}=95,000$ linked by disulfide bonds to give a $\beta-\alpha-\alpha-\beta$ structure $(8,9)$ (Fig. 1). The $\alpha$-subunit appears to be entirely extracellular and contains the insulin binding site. This binding site can be affinity labeled using labeled insulin and bifunctional cross-linking agents $(8,9)$ or photoaffinity insulin analogues $(10,11)$. Although there are two $\alpha$-subunits per receptor, there is still debate as to whether the holoreceptor contains one or two insulin binding sites in its native form (12, 13). The $\beta$-subunits are transmembrane proteins and are therefore the subunits involved in intracellular signaling (11).

Like the A and B chains of insulin, both the $\alpha$ - and $\beta$-subunits of the insulin receptor are derived from a single-chain precursor or proreceptor (14). During in vitro translation of receptor mRNA (15) or when cells are biosynthetically labeled in the presence of inhibitors of glycosylation (16), this proreceptor can be identified and has a molecular weight of $\sim 160,000$. In the normal intact cell, the proreceptor is rapidly glycosylated to give species of $180-210 \mathrm{kD}$, which are then disulfide linked, cleaved, and further glycosylated to give the tetrameric receptor $(14,16,17)$. In the cells thus far studied, the half-life of the native receptor is $8-12 \mathrm{~h}(14,17)$.

The cDNA for the insulin proreceptor has been cloned from both humans $(18,19)$ and Drosophila $(20)$, and both are very similar. The coding portion of the human cDNA is a little over $4 \mathrm{~kb}$ long and predicts a receptor consisting of 1,346 amino acids. ${ }^{1}$ The 5 '-end of the cDNA begins with a signal sequence. This is followed by the coding sequence for the $\alpha$ subunit (beginning with its $\mathrm{NH}_{2}$-terminus) which, in turn, is followed by the sequence of the $\beta$-subunit. The predicted $\alpha$ subunit sequence includes several sites for N-linked glycosylation, a cysteine-rich domain believed to be involved in insulin binding, but has no apparent transmembrane domain. The $\beta$-subunit, on the other hand, has an extracellular segment also containing sites for $\mathrm{N}$-linked (and possibly O-linked) glycosylation (21), a single transmembrane segment of 23 amino acids, and an intracellular site that is homologous to a number of protein kinases (see below). In the proreceptor, the $\alpha$ and $\beta$

\footnotetext{
1. The two original reports of the human receptor cDNA $(18,19)$ revealed coding sequences that differed in length by 36 bases. These occurred in a single frame near the $\mathrm{COOH}$-terminal sequence of the $\alpha$-subunit. The Ullrich sequence (18) thus predicts a proreceptor of 1,346 amino acids, whereas the Ebina sequence (19) predicts 1,358 amino acids. This may be the result of alternate splicing of the mRNA. In this Perspective, we have numbered the amino acid positions in accordance with the Ullrich sequence, beginning with 1 at the $\mathrm{NH}_{2}$ terminus of the $\alpha$-subunit and continuing sequentially through to the $\mathrm{COOH}$-terminus of the $\beta$-subunit. To determine the analogous position in the Ebina sequence, simply add 12 .
} 


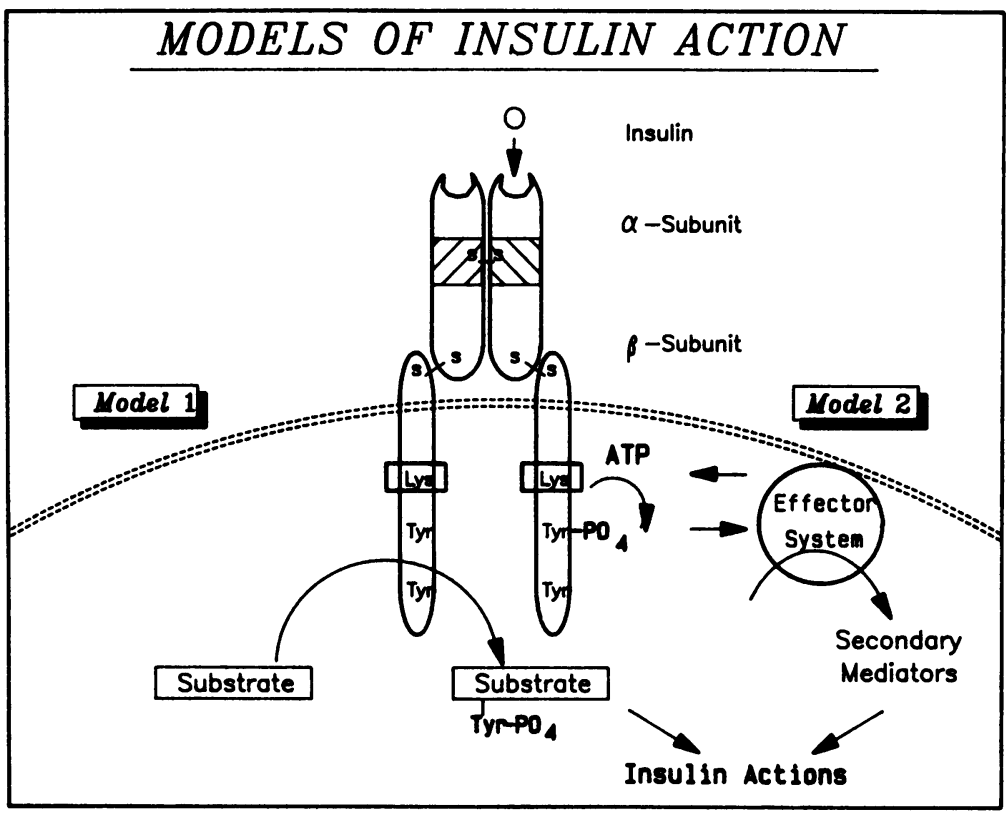

Figure 1. Schematic representation of the insulin receptor and early steps in insulin action. The receptor is as described in the text and consists of two $\alpha$ (binding) subunits and two $\beta$-(kinase) subunits. Insulin binding stimulates the kinase, resulting in autophosphorylation of the receptor on tyrosine residues. Two models of subsequent steps in the pathway are depicted. Model 1 represents the phosphorylation cascade; model 2 represents a noncovalent interaction pathway. Both are described in detail in the text. subunit domains are separated by four basic residues that represent the site for cleavage to the individual subunits.

In human cells, there appears to be a single insulin receptor gene per haploid genome that is on the short-arm of chromosome 19 (22). Genomic Southern analysis and cloning of portions of the $5^{\prime}$ and $3^{\prime}$ regions of the receptor gene indicate that it is at least $150 \mathrm{~kb}$ in size and contains a minimum 17 exons. ${ }^{2}$ In all cells studied, there are multiple species of mRNA $(18,19$, $23,24)$. In human lymphocytes, at least four of these $(5.7,7.1$, 7.9 , and $9.5 \mathrm{~kb}$ ) are larger than the coding sequence. These multiple species appear to result primarily from differences in the length of the $3^{\prime}$-untranslated region (Goldstein, B. J., and C. R. Kahn, unpublished data). ${ }^{3}$ Whether these affect mRNA stability has not yet been determined. The 5 '-untranslated region, like that of so-called house-keeping genes, is GC rich and does not have a TATA or CAAT box (25). ${ }^{3}$ There are several closely spaced initiation start sites in this region. The half-life of the receptor mRNA is human lymphocytes and rat hepatoma cells is $\sim 70-150 \mathrm{~min}(23,24)$.

A major breakthrough in understanding transmembrane signaling by the receptor came in 1982 with the finding that the $\beta$-subunit of the receptor was an insulin-stimulated protein kinase capable of phosphorylating itself and other substrates on tyrosine residues (26). This was further validated by the cDNA cloning, which indicated that the intracellular domain of the $\beta$-subunit of the insulin receptor is highly homologous with several other tyrosine protein kinases including the receptors for epidermal growth factor, platelet-derived growth factor, insulin-like growth factor, and colony-stimulating factor, and a number of oncogene products $(18,19,27)$. The tyrosine protein kinase activity of the insulin receptor and its role in insulin action has been extensively explored in many laboratories. The properties of this kinase can be summarized as follows:

2. Muller-Wieland, D., K. M. Kriauciunas, S. S. K. Reddy, R. A. Taub, and C. R. Kahn, 1988. Diabetes. In press.

3. Taub, R., personal communication. (a) The insulin receptor is an insulin-regulated tyrosine kinase and behaves as a classical allosteric enzyme. Insulin binds to the $\alpha$-subunit and stimulates tyrosine phosphorylation of the $\beta$-subunit of the insulin receptor. This property has been observed in intact cells, solubilized receptor preparations, immunoprecipitated receptors, and the receptor purified to homogeneity (26-30). The solubilized and purified receptor will also phosphorylate other proteins on tyrosine residues including histone 2B, several glycolytic enzymes, cytoskeletal proteins, and a number of natural and synthetic tyrosine-containing peptides (31-33). In each case, ATP acts as the phosphate donor, and phosphorylation occurs exclusively on tyrosine residues. Insulin stimulates the kinase by increasing the catalytic velocity $\left(V_{\max }\right)$ rather than by changing substrate affinity (34). The exact mechanism of the insulin stimulation is unknown, but appears to involve a release of an inhibitory effect exerted by the $\alpha$-subunit on $\beta$-subunit function. Thus, removal of the insulin binding domain of the $\alpha$-subunit by either mild tryptic treatment (35) or in vitro mutagenesis (36) produces an activation of the kinase mimicking the insulin effect.

(b) Receptor kinase activity is regulated by multi-site phosphorylation. Autophosphorylation of the insulin receptor occurs through a cascade of intramolecular phosphorylation. As a result, at least five tyrosines in the intracellular portion of the $\beta$-subunit are phosphorylated. Three of these tyrosines occur in a cluster at residues 1146,1150 , and 1151 on the $\beta$-subunit $(37,38)$. When all three of these tyrosines are phosphorylated, the kinase is further activated toward exogenous substrates (37). This may be important for signal transduction, since kinase activity remains enhanced as long as dephosphorylation does not occur, even if insulin is allowed to dissociate from the receptor $(39,40)$. Changing tyrosines 1150 and 1151 to phenylalanines by in vitro mutagenesis results in a receptor that is not fully activated as a kinase and is inefficient in signal transduction (41). There are also two tyrosine phosphorylation sites in the COOH-terminus of the receptor, but these do not appear to be important in the activation process (42). 
In intact cells, the receptor also undergoes serine and threonine phosphorylation (28). This can be stimulated by both phorbol esters and cAMP analogues and is presumably the result of phosphorylation by protein kinase $C(43-46)$. In contrast to tyrosine phosphorylation, which activates the kinase, serine phosphorylation inactivates the kinase $(46,47)$. This exquisite regulation of insulin receptor kinase activity by multisite phosphorylation provides an important mechanism for regulation of insulin signaling in physiologic and pathologic states (see below).

(c) The tyrosine kinase activity of the insulin receptor is essential for insulin action. Direct evidence that the tyrosine kinase activity of the insulin receptor is required for insulin action has come from several directions. The most convincing evidence is derived from in vitro mutagenesis experiments in which a lysine residue at position 1018 has been changed to one of several other amino acids. Based on analogy to other kinases, this residue is in the ATP binding site of kinase (18, $19,27)$. When such mutants are expressed in cells, they bind insulin normally, but are totally inactive as kinases and are totally ineffective in mediating insulin stimulation of cellular metabolism $(48,49)$. This is true for all effects of insulin, including both the acute metabolic and more chronic growthpromoting effects of the hormone. As noted above, mutagenesis of one of the major autophosphorylation sites produces similar but less dramatic effects (41).

An important role for receptor kinase activity is also illustrated by the effects of antibodies to either intracellular domains of the receptor or to phosphotyrosine itself. When introduced into cells, these antibodies inhibit receptor kinase activation and inhibit insulin stimulated effects $(50,51)$. Alterations of receptor kinase in insulin resistant states is also consistent with this notion (see below).

Exactly how the receptor kinase ultimately transmits its signal is still uncertain. Most investigation has focused on a model involving a phosphorylation cascade, i.e., insulin induces receptor autophosphorylation, which activates the receptor kinase, which in turn phosphorylates one or more cellular substrates (Fig. 1, Model 1). These substrates could be enzymes (serine kinases or phosphoprotein phosphatases) or enzyme inhibitors whose activity is changed by this phorphorylation, leading to a cascade of secondary phosphorylation and dephosphorylation reactions. This phosphorylation cascade model is supported by the fact that insulin treatment results in serine phosphorylation and dephosphorylation of several cellular enzymes $(3,4,52-57)$. Some of these dephosphorylations are known to be important in enzyme regulation, particularly for glycogen synthase (53), hormone-sensitive lipase (54), and pyruvate dehydrogenase (55). The serine phosphorylations stimulated by insulin include phosphorylation of ATP citrate lyase (56), acetyl CoA carboxylase (57), S6 kinase (58), and the insulin receptor itself (28). Most of these are of uncertain functional significance, although serine phosphorylation of acetyl CoA carboxylase increases its activity (57).

Several endogenous substrates for the insulin receptor have been uncovered. The first detected in intact cells, and perhaps best studied, is a protein of $\sim 185 \mathrm{kD}$, termed pp185 (59). pp185 or similar high-molecular weight proteins have been observed in all cell types studied $(60,61)$, and their phosphorylation appears to be stimulated by insulin or insulin-like growth factor I, but not by other receptor tyrosine kinases. In cells transfected with the human insulin receptor cDNA, there is a marked enhancement of pp185 phosphorylation coincident with an enhancement of insulin action (62). Recent additional evidence of a role for pp185 phosphorylation in insulin action has come from an unexpected finding after in vitro mutagenesis of the insulin receptor at or around tyrosine 960 . These mutant receptor molecules bind insulin normally and are fully active as kinases in vitro. This is not surprising, since Tyr-960 is neither a site of autophosphorylation nor in the active kinase domain. However, when transfected into cells, these mutant receptors do not phosphorylate pp185 and are not competent for transmission of insulin action (62). Several lower molecular weight endogenous substrates have also been identified (63-65). Attempts to purify and specifically identify each of these are currently ongoing in several laboratories.

Not all of insulin's actions on cells, however, can be related to changes in phosphorylation or to a phosphorylation cascade. For example, there is no evidence that insulin stimulates phosphorylation or dephosphorylation of the glucose transporter or any proteins at the glucose transport pathway (62). Furthermore, some monoclonal antibodies to the insulin receptor appear to be able to stimulate glucose transport without activating the receptor kinase (66). These observations have led to a second model of action, in which receptor autophosphorylation is viewed as changing the conformation of the receptor $\beta$-subunit, allowing it to interact noncovalently with some other effector system (Fig. 1, Model 2). Evidence for a conformational change after autophosphorylation has come from studies using antibodies to specific domains of the $\beta$-subunit, some of which will bind to the receptor only after it undergoes phosphorylation (67) (Perlman, R., M. F. White, and C. R. Kahn, unpublished data).

Secondary effector systems might include phosphatidylinositol kinases or phospholipases. Phosphatidylinositol kinase activity has been observed in immunoprecipitates of the insulin receptor kinase $(68,69)$ and in association with other tyrosine kinase (70-72). Insulin action on cells also appears to activate one or more phospholipases, including a specific phospholipase $\mathrm{C}$ that may generate an inositol glycan compound capable of mimicking several of insulin's actions on cells (73-75). These effector systems may be linked indirectly, i.e., via a $\mathrm{G}$ protein or a ras-related protein, rather than directly to the receptor. Pertussis toxin treatment, which inhibits the guanyl nucleotide binding protein $\mathbf{G}_{i}$, inhibits some of insulin's actions $(76,77)$, and insulin treatment of membranes inhibits pertussis toxin catalyzed ADP ribosylation (78). In vitro, the insulin receptor will phosphorylate $G$ proteins and related molecules such as transducin (31); however, this does not appear to occur in intact cells. Antibodies to ras-related proteins also inhibit insulin actions when introduced into some cell types (79).

Since the insulin receptor lies at the pivotal point in signal transmission between the circulating hormone and the intracellular milieu, it is obvious that alterations in receptor expression or function can play important roles in both physiologic and pathologic states. This concept has led to extensive characterization of the receptor in a wide variety of disease states. Evidence for genetic alterations in the insulin receptor have been presented in patients with several relatively rare forms of insulin resistance, including the type A syndrome of insulin resistance (80-82), leprechaunism $(81,83)$, and lipoatrophic diabetes (84). Several patients with these syndromes have low numbers of receptors, and in some this can be ac- 
counted for by a decrease in receptor mRNA $(84,85)$. Very recent studies in three of these patients have revealed point mutations in the receptor mRNA leading to altered receptor sequences. One patient has mutations in both alleles coding for the region of the $\alpha$-subunit. One mutation leads to a substitution of lysine at position 460 by glutamic acid; the other leads to a premature stop codon (86). A second patient has a mutation at the $\alpha-\beta$ processing site leading to altered cleavage of the proreceptor (87). In this patient, the proreceptor is expressed at the cell surface but has reduced binding affinity and decreased signal capacity. The third patient has a mutation at residue 1188 in the kinase domain of the $\beta$-subunit leading to a substitution of serine for tryptophan $(88,89)$. This also leads to reduced kinase activity of the receptor.

In more common insulin-resistant diabetic states, like type II diabetes, there is also altered receptor number or function, but these appear to be regulatory in nature. In most hyperinsulinemic states, receptor concentrations are decreased due to down-regulation of receptors (90). In obese animals, this is associated with an increase, rather than decrease, of receptor mRNA (91). Interestingly, altered receptor kinase activity is also present in both type I and II diabetes. In type II diabetes, there is a decrease in insulin-stimulated receptor autophosphorylation and kinase activity that is above and beyond the decrease that can be accounted for by reduced receptor number (92-96). In insulin-deficient type I diabetes, at least in rodent models, there is a decrease in kinase activity despite increased receptor number (97-99). The alterations in both type I and II diabetes appear to be regulatory, since they are improved by treatment of the disease. Furthermore, identical twins discordant for diabetes are also discordant for the kinase defect. Whether these regulatory defects reflect alterations in receptor serine phosphorylation is unknown. Clearly, however, this is a site for potential future therapeutic manipulation in diabetes, since altering receptor signal transduction could enhance the sensitivity to insulin in type II diabetes, and may even substitute for insulin-induced signaling in type I diabetes.

\section{References}

1. Freychet, P., J. Roth, and D. M. Neville, Jr. 1971. Insulin receptors in the liver: specific binding of $\left[{ }^{125} \mathrm{I}\right]$ insulin to the plasma membrane and its relation to insulin bioactivity. Proc. Natl. Acad. Sci. USA. 68:1833-1837.

2. Cuatrecasas, P. 1972. Affinity chromatography and purification of the insulin receptor of liver cell membranes. Proc. Natl. Acad. Sci. USA. 69:1277-1281.

3. Kahn, C. R. 1985. Current concepts of the molecular mechanism of insulin action. Annu. Rev. Med. 36:429-451.

4. Czech, M. P. 1984. The nature and regulation of the insulin receptor. Annu. Rev. Physiol. 47:357-381.

5. Pullen, R. A., D. G. Lindsay, S. P. Wood, I. J. Tickle, T. L. Blundell, A. Wollmer, G. Krail, D. Brandenburg, H. Zahn, J. Gliemann, and S. Gammeltoft. 1976. Receptor-binding region of insulin. Nature (Lond.). 259:369-373.

6. Anderson, O., J. Gliemann, and S. Gammeltoft. 1977. Receptor binding and biological effect of insulin in human adipocytes. Diabetologia. 13:589-593.

7. Muggeo, M., B. H. Ginsberg, J. Roth, D. M. Neville, Jr., P. DeMeyts, and C. R. Kahn. 1979. The insulin receptor in vertebrates is functionally more conserved during evolution than insulin itself. Endocrinology. 104:1383-1392.

8. Massague, J., P. F. Pilch, and M. P. Czech. 1981. Electrophoretic resolution of three major insulin receptor structures with unique subunit stoichiometries. Proc. Natl. Acad. Sci. USA. 77:7137-7141.

9. Kasuga, M., J. A. Hedo, K. M. Yamada, and C. R. Kahn. 1982. Structure of insulin receptor and its subunits. J. Biol. Chem. 257:10392-10399.

10. Yip, C. C., C. W. T. Yeung, and M. L. Moule. 1978. Photoaffinity labeling of insulin receptor of rat adipocyte plasma membrane. $J$. Biol. Chem. 253:1743-1745.

11. Hedo, J. A., and I. A. Simpson. 1984. Internalization of insulin receptors in the isolated rat adipose cell. J. Biol. Chem. 259:1108311089.

12. Fujita-Yamaguchi, Y. 1984. Characterization of purified insulin receptor subunits. J. Biol. Chem. 259:1206-1211.

13. Sweet, L. J., B. D. Morrison, and J. F. Pessin. 1987. Isolation of functional $\alpha \beta$ heterodimers from the purified human placental $\alpha_{2} \beta_{2}$ heterotetrameric insulin receptor complex. J. Biol. Chem. 161:69396942.

14. Hedo, J. A., C. R. Kahn, M. Hayoshi, K. M. Yamada, and M. Kasuga. 1983. Biosynthesis and glycosylation of the insulin receptor. Evidence for a single polypeptide precursor of the two major subunits. J. Biol. Chem. 258:10020-10026.

15. Goldstein, B., and C. R. Kahn. 1988. Initial processing of the insulin receptor in vivo and in vitro. J. Biol. Chem. In press.

16. Ronnett, G. V., V. P. Knutson, R. A. Kohanski, T. L. Simpson, and M. D. Lane. 1984. Role of glycosylation in the processing of newly translated insulin proreceptor in 3T3-L1 adipocytes. J. Biol. Chem. 259:4566-4575.

17. Deutsch, P. J., C. F. Wan, O. M. Rosen, and C. S. Rubin. 1983. Latent insulin receptors and possible receptor precursors in 3T3-L1 adipocytes. Proc. Natl. Acad. Sci. USA. 80:133-136.

18. Ullrich, A., J. R. Bell, E. Y. Chen, R. Herrera, L. M. Petruzzelli, T. J. Dull, A. Gray, L. Coussens, Y.-C. Liao, M. Tsubokawa, A. Mason, P. H. Seeburg, C. Grunfeld, O. M. Rosen, and J. Ramachandran. 1985. Human insulin receptor and its relationship to the tyrosine kinase family of oncogenes. Nature (Lond.). 313:756-761.

19. Ebina, Y., L. Ellis, K. Jarnagin, M. Edery, L. Graf, E. Clauser, J.-H. Ou, F. Masiar, Y. W. Kan, I. D. Goldfine, R. A. Roth, and W. J. Rutter. 1985. Human insulin receptor cDNA: the structural basis for hormone activated transmembrane signalling. Cell. 40:747-758.

20. Petruzzelli, L., R. Herrera, R. Arenas Garcia, R. Fernandez, M. J. Birnbaum, and O. M. Rosen. 1986. Isolation of a Drosophila genomic sequence homologous to the kinase domain of the human insulin receptor and detection of the phosphorylated Drosophila receptor with an anti-peptide antibody. Proc. Natl. Acad. Sci. USA. 83:4710-4714.

21. Herzberg, V. L., F. Grigorescu, A. S. B. Edge, R. G. Spiro, and C. R. Kahn. 1985. Characterization of insulin receptor carbohydrate by comparison of chemical and enzymatic deglycosylation. Biochem. Biophys. Res. Commun. 129:789-796.

22. Yang Feng, T. L., U. Francke, and A. Ullrich. 1985. Gene for human insulin receptor: localization to site on chromosome 19 involved in pre-B-cell leukemia. Science (Wash. DC). 228:728-731.

23. Goldstein, B. J., D. Muller-Wieland, and C. R. Kahn. 1987. Variation in insulin receptor mRNA expression in human and rodent tissues. Mol. Endocrinol. 1:759-766.

24. McDonald, A. R., and I. G. Goldfine. 1988. Glucocorticoid regulation of insulin receptor gene transcription in IM-9 cultured lymphocytes. J. Clin. Invest. 81:499-504.

25. Araki, E., F. Shimada, A. Uzawa, M. Mori, and Y. Ebina. 1987. Characterization of the promoter region of the human insulin receptor gene. J. Biol. Chem. 262:16186-16191.

26. Kasuga, M., F. A. Karlsson, and C. R. Kahn. 1982. Insulin stimulates the phosphorylation of the 95,000-dalton subunit of its own receptor. Science (Wash. DC). 215:185-187.

27. White, M. F., and C. R. Kahn. 1986. The Insulin Receptor and Tyrosine Phosphorylation. In The Enzymes. P. D. Boyer and E. G. Krebs, editors. Academic Press, Inc., Orlando, FL 247-302.

28. Kasuga, M., Y. Zick, D. L. Blithe, F. A. Karlsson, H. U. Haring, 
and C. R. Kahn. 1982. Insulin stimulation of phosphorylation of the B-subunit of the insulin receptor: formation of both phosphoserine and phosphotyrosine. J. Biol. Chem. 257:9891-9894.

29. Petruzzelli, L. M., S. Gangaly, C. R. Smith, M. H. Cobb, C. S. Rubin, and O. M. Rosen. 1982. Insulin activates a tyrosine specific protein kinase in extracts of 3T3-L1 adipocytes and human placenta. Proc. Natl. Acad. Sci. USA. 79:6792-6796.

30. Avruch, J., R. A. Nemenoff, P. J. Blackshear, M. W. Pierce, and R. Osathanondh. 1982. Insulin-stimulated tyrosine phosphorylation of the insulin receptor in detergent extracts of human placental membranes: comparison to EGF-stimulated phosphorylation. J. Biol. Chem. 257:15162-15166.

31. Zick, Y., R. Sagi Eisenberg, M. Pines, P. Gierschik, and A. M. Spiegel. 1986. Multisite phosphorylation of the alpha subunit of transducin by the insulin receptor kinase and protein kinase C. Proc. Natl. Acad. Sci. USA. 83:9294-9297.

32. Sale, E. M., M. F. White, and C. R. Kahn. 1987. Phosphorylation of glycolytic and gluconeogenic enzymes by the insulin receptor kinase. J. Cell. Biochem. 33:15-26.

33. Akiyama, T., T. Kadowaki, E. Nishida, T. Kadooka, H. Ogawara, Y. Fukami, H. Sakai, F. Takaku, and M. Kasuga. 1986. Substrate specificities of tyrosine-specific protein kinases toward cytoskeletal proteins in vitro. J. Biol. Chem. 261:14797-14803.

34. White, M. F., H. U. Haring, M. Kasuga, and C. R. Kahn. 1984. Kinetic properties and sites of autophosphorylation of the partially purified receptor from hepatoma cells. J. Biol. Chem. 259:255-264.

35. Shoelson, S. E., M. F. White, and C. R. Kahn. 1988. Tryptic activation of the insulin receptor. J. Biol. Chem. 263:4852-4860.

36. Ellis, L., D. O. Morgan, E. Clauser, M. Edery, S. M. Jong, L. H. Wang, R. A. Roth, and W. J. Rutter. 1986. Mechanisms of receptormediated transmembrane communication. Cold Spring Harbor Symp. Quant. Biol. 51:2-P773-784.

37. White, M. F., S. E. Shoelson, H. Keutmann, and C. R. Kahn. 1988. A cascade of tyrosine autophosphorylation in the $\beta$-subunit activates the insulin receptor. J. Biol. Chem. 263:2969-2980.

38. Tornqvist, H. E., M. W. Pierce, A. R. Frackelton, R. A. Nemenoff, and J. Avruch. 1987. Identification of insulin receptor tyrosine residues autophosphorylated in vitro. J. Biol. Chem. 262:1021210219.

39. Yu, K.-T., and M. P. Czech. 1984. Tyrosine phosphorylation of the insulin receptor $\beta$-subunit activates the receptor-associated tyrosine kinase activity. J. Biol. Chem. 259:5277-5286.

40. Herrera, R., and O. M. Rosen. 1986. Autophosphorylation of the insulin receptor in vitro. Designation of phosphorylation sites and correlation with receptor kinase activation. J. Biol. Chem. 261:11980-11985.

41. Ellis, L., E. Clauser, D. O. Morgan, M. Edery, R. A. Roth, and W. J. Rutter. 1986. Replacement of insulin receptor tyrosine residues 1162 and 1163 compromises insulin-stimulated kinase activity and uptake of 2-deoxyglucose. Cell. 45:721-732.

42. Goren, H. J., M. F. White, and C. R. Kahn. 1987. Separate domains of the insulin receptor contain sites of autophosphorylation and tyrosine kinase activity. Biochemistry. 26:2374-2381.

43. Takayama, S., M. F. White, V. Lauris, and C. R. Kahn. 1984. Phorbol esters modulate insulin receptor phosphorylation and insulin action in hepatoma cells. Proc. Natl. Acad. Sci. USA. 81:7797-7801.

44. Jacobs, S., and P. Cuatrecasas. 1986. Phosphorylation of receptors for insulin and insulin-like growth factor I. Effects of hormones and phorbol esters. J. Biol. Chem. 261:934-939.

45. Stadtmauer, L., and O. M. Rosen. 1986. Increasing the cAMP content of IM-9 cells alters the phosphorylation state and protein kinase activity of the insulin receptor. J. Biol. Chem. 261:3402-3407.

46. Roth, R. A., and J. Beaudoin. 1987. Phosphorylation of purified insulin receptor by cAMP kinase. Diabetes. 36:123-126.

47. Takayama, S., M. F. White, and C. R. Kahn. 1988. Phorbol ester induced serine phosphorylation of the insulin receptor decreases its tyrosine kinase activity. J. Biol. Chem. 263:3440-3447.

48. Ebina, Y., E. Araki, M. Taira, F. Shimada, M. Mori, C. S.
Craik, K. Siddle, S. B. Pierce, R. A. Roth, and W. J. Rutter. 1987. Replacement of lysine residue 1030 in the putative ATP-binding region of the insulin receptor abolishes insulin- and antibody-stimulated glucose uptake and receptor kinase activity. Proc. Natl. Acad. Sci. USA. 84:704-708.

49. Chou, C. K., T. J. Dull, D. S. Russell, R. Gherzi, D. Lebwohl, A. Ullrich, and O. M. Rosen. 1987. Human insulin receptors mutated at the ATP-binding site lack protein tyrosine kinase activity and fail to mediate postreceptor effects of insulin J. Biol. Chem. 262:1842-1847.

50. Morgan, D. O., and R. A. Roth. 1987. Acute insulin action requires insulin receptor kinase activity: introduction of an inhibitory monoclonal antibody into mammalian cells blocks the rapid effects of insulin. Proc. Natl. Acad. Sci. USA. 84:41-45.

51. Takayama, S., E. W. Stegman, R. Maron, and C. R. Kahn. 1988. The effect of antiphosphotyrosine antibodies on insulin receptor phosphorylation and insulin response in rat hepatoma cells. Diabetes. 35(Suppl. 1):8A. (Abstr.)

52. Czech, M. P., K. T. Yu, R. E. Lewis, R. J. Davis, C. Mottola, R. G. MacDonald, P. C. Necessary, and S. Corvera. 1985. Insulin receptor kinase and its mode of signaling membrane components. Diabetes Metab. Rev. 1:33-58.

53. Sheorain, V. S., B. S. Khatra, and T. R. Soderling. 1982. Hormonal regulation of skeletal muscle glycogen synthase through covalent phosphorylation. Fed. Proc. 41:2618-2622.

54. Stralfros, P., P. Bjorgell, and P. Belfrage. 1984. Hormonal regulation of hormone-sensitive lipase in intact adipocytes: identification of phosphorylated sites and effects on the phosphorylation by lipolytic hormones and insulin. Proc. Natl. Acad. Sci. USA. 81:3317-3321.

55. Hughes, W. A., R. W. Brownsey, and R. M. Denton. 1980. Studies on the incorporation of $\left[{ }^{32} \mathrm{P}\right]$ phosphate into pyruvate dehydrogenase in intact rat fat cells. Biochem. J. 192:469-481.

56. Alexander, M. D., E. M. Kowaloff, L. A. Witters, D. T. Denniky, and J. Avruch. 1979. Purification of a hepatic 123,000-dalton hormone stimulated ${ }^{32} \mathrm{P}$-peptide and its identification as ATP-citrate lyase. J. Biol. Chem. 254:8052-8056.

57. Brownsey, R. M., and R. M. Denton. 1982. Evidence that insulin activates fat-cell acetyl-CoA carboxylase by increased phosphorylation at a specific site. Biochem. J. 202:345-352.

58. Cobb, M. N., and O. M. Rosen. 1983. Description of a protein kinase derived from insulin-treated 3T3-L1 cells that catalyzes the phosphorylation of ribosomal protein S6 and casein. J. Biol. Chem. 258:12472-12481.

59. White, M. F., R. Maron, and C. R. Kahn. 1985. Insulin rapidly stimulates tyrosine phosphorylation of a $M_{\mathrm{r}}=185,000$ protein in intact cells. Nature (Lond.) 318:183-186.

60. White, M. F., E. W. Stegmann, T. J. Dull, A. Ulrich, and C. R. Kahn. 1987. Characterization of an endogenous substrate of the insulin receptor in cultured cells. J. Biol. Chem. 262:9769-9777.

61. Gibbs, E. M., W. J. Allard, and G. E. Lienhard. 1986. The glucose transporter in 3T3-L1 adipocytes is phosphorylated in response to phorbol ester but not in response to insulin. J. Biol. Chem. 261:16597-16603.

62. White, M. F., J. N. Livingston, J. M. Backer, T. Dull, A. Ullrich, and C. R. Kahn. 1988. Mutation of the insulin receptor at tyrosine 960 inhibits signal transmission but does not affect tyrosine kinase activity. Cell. In press.

63. Rees-Jones, R. W., and S. I. Taylor. 1984. An endogenous substrate for the insulin receptor associated tyrosine kinase. J. Biol. Chem. 260:4461-4467.

64. Bernier, M., D. M. Laird, and M. D. Lane. 1987. Insulin-activated tyrosine phosphorylation of a 15-kilodalton protein in intact 3T3-L1 adipocytes. Proc. Natl. Acad. Sci. USA. 84:1844-1848.

65. Haring, H. U., M. F. White, F. Machicao, B. Ermel, E. Schleicher, and B. Obermaier. 1987. Insulin rapidly stimulates phosphorylation of a $46-\mathrm{kDa}$ membrane protein on tyrosine residues as well as phosphorylation of several soluble proteins in intact fat cells. Proc. Natl. Acad. Sci. USA. 84:113-117.

66. Forsayeth, J. R., J. F. Caro, M. K. Sinha, B. A. Maddux, and 
I. D. Goldfine. 1987. Monoclonal antibodies to the human insulin receptor that activate glucose transport but not insulin receptor kinase activity. Proc. Natl. Acad. Sci. USA. 84:3448-3451.

67. Herrera, R., L. Petruzzelli, N. Thomas, H. N. Bramson, E. T. Kaiser, and O. M. Rosen. 1985. An antipeptide antibody that specifically inhibits insulin receptor autophosphorylation and protein kinase activity. Proc. Natl. Acad. Sci. USA. 82:7899-7903.

68. Sale, G. J., Y. Fujita Yamaguchi, and C. R. Kahn. 1986. Characterization of phosphatidylinositol kinase activity associated with the insulin receptor. Eur. J. Biochem. 155:345-351.

69. Machicao, F., and O. H. Wieland. 1984. Evidence that the insulin receptor-associated protein kinase acts as a phosphatidylinositol kinase. FEBS (Fed. Eur. Biochem. Soc.) Lett. 175:113-116.

70. Kaplan, D. R., M. Whitman, B. Schaffhausen, D. C. Pallas, M. F. White, L. Cantley, and T. M. Roberts. 1987. Common elements in growth factor stimulation and oncogenic transformation: $85 \mathrm{kDa}$ phosphoprotein and phosphatidylinositol kinase activity. Cell. 50:1021-1029.

71. Walker, D. H., D. Kuppuswamy, A. Visvanathan, and L. J. Pike. 1987. Substrate specificity and kinetic mechanism of human placental insulin receptor kinase. Biochemistry. 26:1428-1433.

72. Sugimoto, Y., M. Whitman, L. D. Cantley, and R. L. Erikson. 1984. Evidence that the Rous sarcoma virus transforming gene product phosphorylates phosphatidylinositol and diacylglycerol. Proc. Natl. Acad. Sci. USA. 81:2117-2121.

73. Saltiel, A. R., and P. Cuatrecasas. 1986. Insulin stimulates the generation from hepatic plasma membranes of modulators derived from an inositol glycolipid. Proc. Natl. Acad. USA. 83:5793-5797.

74. Romero, G., L. Luttreli, A. Rogol, K. Zeller, E. Hewlett, and J. Larner. 1988. Phosphatidylinositol-glycan anchors of membrane proteins: potential precursors of insulin mediators. Science (Wash. DC). 240:509-512.

75. Kelly, K. L., J. M. Mato, I. Merida, and L. Jarrett. 1987. Glucose transport and antilipolysis are differentially regulated by the polar head group of an insulin-sensitive glyopholipid. Proc. Natl. Acad. Sci. USA. 84:6404-6407.

76. Houslay, M. D. 1986. Insulin, glucagon and the receptor-mediated control of cyclic AMP concentrations in liver. Twenty-second Colworth medal lecture. Biochem. Soc. Trans. 14:183-193.

77. Goren, H. J., J. K. Northup, and M. D. Hollenberg. 1985. Action of insulin modulated by pertussis toxin in rat adipocytes. Can. J. Physiol. Pharmacol. 63:1017-1022.

78. Rothenberg, P., and C. R. Kahn. 1988. Insulin inhibits pertussus-toxin catalyzed ribosylation of G-proteins. J. Biol. Chem. In press.

79. Korn, L. J., C. W. Siebel, F. McCormick, and R. A. Roth. 1987. Ras p21 as a potential mediator of insulin action in Xenopus oocytes. Science (Wash. DC). 236:840-843.

80. Grigorescu, F., J. S. Flier, and C. R. Kahn. 1986. Characterization of binding and phosphorylation defects of erythrocyte insulin receptors in the type A syndrome of insulin resistance. Diabetes. 35:127-138.

81. Grigorescu, F., V. Herzberg, G. King, M. Meistas, J. Elders, T. Frazer, and C. R. Kahn. 1987. Defects in insulin binding and autophosphorylation of erythrocyte insulin receptors in patients with syndromes of severe insulin resistance and their parents. J. Clin. Endocrinol. \& Metab. 64:549-556.

82. Grunberger, G., R. J. Canu, S. I. Taylor, and P. Gorden. 1984. Tyrosine kinase activity of the insulin receptor of patients with Type A extreme insulin resistance: studies with circulating mononuclear cells and cultured lymphocytes. J. Clin. Endocrinol. \& Metab. 59:11521158.
83. Taylor, S. I., B. Samuels, J. Roth, M. Kasuga, J. A. Hedo, P. Gorden, D. E. Barsel, T. Pokora, and R. R. Engel. 1982. Decreased insulin binding in cultured lymphocytes from two patients with extreme insulin resistance. J. Clin. Endocrinol. \& Metab. 54:919-930.

84. Kriauciunas, K. 1988. Altered expression and function of the insulin receptor in a family with lipoatrophic diabetes. J. Clin. Endocrinol. \& Metab. In press.

85. Ojamaa, K., J. A. Hedo, C. T. Roberts, Jr., V. Y. Moncada, P. Gorden, A. Ullrich, and S. I. Taylor. 1988. Defects in human insulin receptor gene expression. Mol. Endocrinol. 2:242-247.

86. Kadowaki, T., C. Berins, A. Cama, K. Ojamaa, B. MarcusSamuels, H. Kadowaki, L. Beitz, C. McKeon, and S. I. Taylor. 1988. Two mutant alleles of the insulin receptor gene in a patient with extreme insulin resistance. Science (Wash. DC). 240:787-790.

87. Yoshimasa, Y., S. Seino, J. Whittaker, T. Kakehi, A. Kosaki, H. Kuzuya, H. Imura, G. I. Bell, and D. F. Steiner. 1988. Insulinresistant diabetes due to a point mutation that prevents insulin proreceptor processing. Science (Wash. DC). 240:784-787.

88. Moller, D., and J. S. Flier. 1988. Polymerase chain reaction (PCK) for analysis of human insulin receptor genetic sequences. Clin. Res. 36:587a. (Abstr.)

89. Goldstein, B., and C. R. Kahn. 1988. Mutation in insulin recpetor $\alpha$-subunit mRNA detected by ribonuclease cleavage in a patient with lipoatrophic diabetes. Clin. Res. 36:584a. (Abstr.)

90. Bar, R. S., L. C. Harrison, M. Muggeo, P. Gorden, C. R. Kahn, and J. Roth. 1979. Regulation of insulin receptors in normal and abnormal physiology in humans. Adv. Intern. Med. 24:23-46.

91. Ludwig, S., D. Muller-Wieland, B. J. Goldstein, and C. R. Kahn. 1988. The insulin receptor gene and its expression in insulin resistant mice. Endocrinology. 123:594-600.

92. Caro, J. F., O. Ittoop, W. J. Pories, D. Meelheim, E. G. Flickinger, F. Thomas, M. Jenquin, J. F. Silverman, P. G. Khazanie, and M. K. Sinha. 1986. Studies on the mechanism of insulin resistance in the liver from humans with noninsulin-dependent diabetes. Insulin action and binding in isolated hepatocytes, insulin receptor structure, and kinase activity. J. Clin. Invest. 78:249-258.

93. Comi, R. J., G. Grunberger, and P. Gorden. 1987. Relationship of insulin binding and insulin-stimulated tyrosine kinase activity is altered in type II diabetes. J. Clin. Invest. 79:453-462.

94. Freidenberg, G. R., R. R. Henry, H. H. Klein, D. R. Reichart, and J. M. Olefsky. 1987. Decreased kinase activity of insulin receptors from adipocytes of non-insulin-dependent diabetic subjects. J. Clin. Invest. 79:240-250.

95. Takayama, S., C. R. Kahn, K. Kubo, and J. E. Foley. 1988. Alterations in insulin receptor autophosphorylation in insulin resistance: correlation with altered sensitivity to glucose transport and anti-lipolysis to insulin. J. Clin. Endocrinol. \& Metab. 66:992-990.

96. Arner, P., K. Einarrson, S. Ewerth, and J. Livingston. 1986. Studies of the human liver receptor in non-insulin dependent diabetes mellitus. J. Clin. Invest. 77:1716-1718.

97. Kadowaki, T., M. Kasuga, Y. Akanuma, O. Ezaki, and F. Takaku. 1984. Decreased autophosphorylation of the insulin receptor-kinase in streptozotocin-diabetic rats. J. Biol. Chem. 259:1420814216.

98. Okamoto, M., M. F. White, R. Maron, and C. R. Kahn. 1986. Autophosphorylation and kinase activity of insulin receptor in diabetic rats. Am. J. Physiol. 251:542-550.

99. Gherzi, R., G. Andraghetti, E. Ferrannini, and R. Cordera. 1986. Insulin receptor autophosphorylation and kinase activity in streptozotocin diabetic rats. Effect of a short fast. Biochem. Biophys. Res. Commun. 140:850-856. 